\title{
Security Measures as a Factor in the Competitiveness of Accommodation Facilities
}

\author{
Rafał Nagaj ${ }^{1, *(1)}$ and Brigita Žuromskaitè ${ }^{2}$ (I) \\ 1 Institute of Economics and Finance, University of Szczecin, 71-101 Szczecin, Poland \\ 2 Faculty of Public Governance, Mykolas Romeris University, 08303 Vilnius, Lithuania; brigitaz@mruni.eu \\ * Correspondence: rafal.nagaj@usz.edu.pl
}

Received: 21 March 2020; Accepted: 15 May 2020; Published: 19 May 2020

\begin{abstract}
The main aim of this article was to assess whether the level of competitiveness of accommodation facilities results from the level of safety and security provided to consumers of these services, measured by the number of security measures applied in them. The authors' task was to examine the level of concentration of security measures in the accommodation facilities and to assess whether the quality of services measured by the star-rating system provided a higher level of safety and security for customers of the accommodation facilities, measured by the number of security measures applied in them. It was decided to examine whether the level of concentration of security measures at the accommodation facilities was treated by these entities as a factor of their competitiveness. Two locations in Central and Eastern Europe, one in Poland and one in Lithuania, were analyzed. The article calculated the frequency of these measures at the accommodation facilities by type of facility (according to the star-rating system) and type of security measure (as a weighted average) and their concentration using the Herfindahl-Hirscham Index. The results showed that the higher the quality of services provided (more stars), the higher the level of safety and security is ensured. It was also found that a higher level of security was not reflected in the prices of accommodation services.
\end{abstract}

Keywords: accommodation; security measures; level of competitiveness

\section{Introduction}

Tourism is among the fastest growing economic sectors in the world, recording long-term growth in international tourist arrivals and receipts (World Tourism Organization 2019). However, as events in recent years have shown, the tourist industry is increasingly exposed to various types of threats and risks (e.g., political threats, natural disasters, diseases and many others) that can have a direct impact on the life and health of the traveler (Rittichainuwat and Chakraborty 2012; Ghazi 2015; Žuromskaite and Nagaj 2018; Chauhan and Negi 2018). Thus, the issue of security has become part of everyday life and an issue closely related to tourism (Chan and Lam 2013). Every event in the world (e.g., terrorist attacks, new viruses, natural disasters, economic crises) that directly affects tourists also has a negative impact on the income and tourist attendance of particular tourist destinations (Kubickova et al. 2019; OECD 2020), as well as financial markets (Lee et al. 2018), which indirectly increases the effect of this impact. However, depending on the geographical location, state policy or economic situation in the country, threats may affect the development of tourism in different ways. It should also be remembered that the same threats do not occur everywhere, as they may vary from region to region.

In order to ensure that tourism continues to develop and generate income for tourist regions, all participants in this sector should pay more attention to the safety and security of their customers. This is due to the fact that when deciding on a tourist trip, tourists choose a tourist destination and a hotel, or more broadly, an accommodation facility, guided not only by the criterion of price, but also by the level of security in these facilities (Rittichainuwat and Chakraborty 2012; Garg and Kumar 2017). 
This is because people usually have an aversion to risk. This is despite the fact that when the profit increases, i.e., in the case of a tourist paying a lower price for the rental, the risk may be still limited (Wilhelmsson and Zhao 2018). Therefore, there is a need to invest in the tourism sector to ensure the security of tourists by installing security measures. Of course, they are not the same everywhere, as there are different threats in a given region or tourist destination. As the literature points out (Feickert et al. 2006; Rittichainuwat and Chakraborty 2012) these measures may be "hard" or "soft". However, not all tourists like "hard" security measures, as those that are too visible can frighten them and adversely affect the quality of their holiday (Žuromskaitè and Nagaj 2018; K1lıçlara et al. 2018). The accommodation facilities want to remain open and hospitable (Feickert et al. 2006). Therefore, so-called "soft" security measures are often used in tourist infrastructure. Modern technologies are useful here, the use of which can effectively contribute to protecting tourists from potential threats (Kilıçlara et al. 2018).

All these activities that are undertaken in the tourist infrastructure and especially in the accommodation infrastructure, which is often "Home away from home" for travelers (Chauhan and Negi 2018, p. 119), are to improve the quality of their services.

The competitive advantage of a company can be proven by many factors. These may be economic, political, ecological, cultural or technical factors. The literature on tourism competitiveness (Goffi et al. 2019; Croes et al. 2020) shows that there are two main areas where you can try to gain a competitive advantage. The first one is about the well-being of clients, i.e., improving the quality of services provided to tourists, and the second is about the market position of a given destination compared to other competitive ones, i.e., promoting itself based on the popularity of a given region or country.

One of the elements influencing the quality of services in tourism may be the level of safety that tourist accommodation facilities provide for tourists through the level of security, and more specifically the number of security measures installed. In the tourism sector the yardstick for assessing the level of quality is the star rating of the accommodation facilities. It is therefore assumed that the number of stars awarded to the establishments also indicates the level of security offered by these establishments to their clients, measured by the number of security measures applied in them. So far, the information security of four- and five-star hotels (Kim et al. 2013) has been studied. However, no analysis has been made as to whether the star-rating system also reflects the level of security offered to customers by the accommodation facilities.

The main aim of this article was to assess whether the level of competitiveness in the tourism sector, more specifically of accommodation facilities, resulted from the level of security provided to consumers of these services, measured by the number of security measures applied in them. The authors' task was to examine the level of concentration of security measures in the accommodation facilities, and to assess whether the higher number of stars provided a higher level of security measured by the number of security measures applied in them. Thus, it will be possible to assess the extent to which security measures are used at accommodation facilities by the type of security measures and the type of accommodation facility evaluated. This will make it possible to determine whether the level of security is treated by the accommodation facilities as a criterion of the quality of the services they provide and thus a factor of their competitiveness. In addition, the survey will enable us to check whether similar security measures were applied in the studied cities from two different countries. A further task will be to assess whether the number of security measures installed correlates with the prices offered by the tested facilities.

The research object was an accommodation facility in two port and holiday resorts (cities) in Central and Eastern European countries, and the method used to assess the concentration of security measures at the accommodation facilities was the Herfindahl-Hirscham Index (HHI).

The research undertaken in this paper is a novelty in the literature, which is due to several reasons. First of all, it has been assumed that the factor ensuring competitiveness in the sector may be the level of security, measured by the number of security measures applied in the accommodation facilities. 
To date, the literature has studied the issue of the impact of safety and security on the development of the tourism sector quite extensively. Moreover, it has studied how safety and security is assessed by tourists. However, it was not examined whether the quality of the services used in accommodation facilities, and thus their competitiveness, was related to the number of security measures applied in them. The second argument for the added value of this work is to examine the level of security at the accommodation facilities and assess whether this corresponds to the number of stars awarded to such establishments. The third argument of novelty is the use of the Herfindahl-Hirscham (HHI) measure to assess the security level of the accommodation facilities. This is a measure of diversity applied in the literature of many fields of science, but has not yet been used to measure the level of concentration and diversity of security measures in accommodation facilities.

The work structure is as follows. After the introduction presented above, a literature review will be presented on the factors determining the choice of an accommodation facility by tourists, and thus the elements that prove a competitive advantage in tourism and the security measures used in accommodation facilities. The next part will be the methodology of research conducted by the authors, after which attention will be focused on the results of these studies. The work will end with the conclusions and discussion.

\section{Literature Review}

Every year many new accommodation facilities are built around the world. However, the answer to the question of whether tourists will be willing to use them and to what extent is difficult to answer, as demand depends on many factors. Among the main criteria for selecting accommodation facilities by tourists, the literature distinguishes hotel location (Aksoy and Ozbuk 2017; Fang et al. 2019), the quality of services offered by the accommodation facility (Baber et al. 2015) and the price and security level (Chen and Gursoy 2001; Chan and Lam 2013). In addition, there are also more specific factors that determine the choice of accommodation, among which are the star rating, years after opening, service diversification, ownership, agglomeration effect, public service infrastructure, road accessibility and subway accessibility (Yang et al. 2012), service quality, business facilities, value, room and front desk, food and recreation and security (Chu and Choi 2000).

The aforementioned factors of choice of the accommodation by tourists are of interest to the owners and to the tourism sector, as they provide information about the area in which the owners should improve their business offer and improve their competitiveness in relation to the competition, and which factors determine tourist destination competitiveness.

One of the factors determining the choice of an accommodation facility by tourists, and therefore also an area where the owners of such facilities can gain a competitive advantage over others, is the level of security, and therefore also the safety in these facilities (Rittichainuwat and Chakraborty 2012). Especially in the twenty-first century, tourists want to feel relatively safe in tourist destinations and accommodation facilities. Security and safety are not identical concepts, although they are connected. The distinction between them was presented by Kôvári and Zimányi (2011, p. 60) who held the view that "security and safety has become a complex multi-dimensional notion with a wide range of components belonging to it: political security, public safety, health and sanitation, personal data safety, legal protection of tourists, consumer protection, safety in communication, disaster protection, environmental security, getting authentic information, quality assurance of services etc.". Namely, the owners of accommodation facilities should provide adequate "security", i.e., by installing security measures appropriate to the potential risks, so that the tourist feels safe and to provide them with an appropriate level of safety. Sometimes visible but "soft" security measures can help a visitor feel more secure and safe.

The problem of the safety and security of tourists is particularly important because if guests encounter any security problems during their stay in the accommodation facility, it leads to dissatisfaction and thus to higher discomfort. The consequence of such a situation is that tourists resign from such facilities in favor of other hotels and their buying consumer behavior becomes 
variety-seeking consumer behavior (Chauhan and Negi 2018). It is particularly important that young people, who represent a large part of the tourism market, do not trust the state but their friends and relatives (Nagaj and Szkudlarek 2019). Therefore, to a large extent they will be guided by the opinion of other people about such facilities. On the other hand, if tourists do not have problems with safety and security during their stay in an accommodation facility, it leads to the satisfaction of guests (Chauhan and Negi 2018). As the literature indicates, nowadays, when deciding about a tourist trip, tourists have started to evaluate tourism infrastructure not only with respect to the possibility of meeting other people, resting and using various amenities, but also in terms of safety and security. As Hilliard and Baloglu (2008) argue, people are willing to pay more for an accommodation facility with a safety and security certificates.

However, it is also important to remember about the other side of the tourism sector, i.e., entrepreneurs. The owners of some tourist facilities often think that security measures may have a negative impact on their business or that such investments are not needed because "it can't happen here" (Pizam 2010; Ghazi 2015). With regards to security measures at accommodation facilities, it is essential that they are not visible and do not interfere with the comfort/peace of the guests. Facility owners believe that the use of too many visible security measures may create an atmosphere of "alarm" among tourists and discourage them from visiting such places. It should also be taken into account that the problem of security and the type of security measures used at accommodation facilities depend on the "age" of the facility. As noted by Ghazi (2015, p. 3), older accommodation facilities are often not designed to ensure security (e.g., have no shatter-proof glass, bomb-proof Kevlar wallpaper or tamper-resistant doors/windows) (Ghazi 2015, p. 3). As a result, the potential investment outlays at such facilities, necessary to create an adequate level of security, may be much higher. For this reason, older accommodation facilities have usually fewer security measures.

The literature generally distinguishes two types of security measures: "soft" and "hard" (Survila et al. 2017). The former are considered less visible and less interfering with the comfort and leisure of the guests. They are more likely to be accepted and do not cause a sense of fear (Feickert et al. 2006; Rittichainuwat and Chakraborty 2012). The latter are more invasive, create a sense of "alarm", but are more effective in ensuring tourists' safety and security. They are more accepted by people under 40 years of age as well as women (Feickert et al. 2006). However, the main goal of both types of security measures is to reduce the risk, ensure tourists' safety and security and minimize the potential economic losses that could arise from it (Henderson 2007).

The increasing level of risk worldwide has led accommodation facilities, especially hotels, to invest in improved security (Howie 2005). Some of the security measures have become commonplace and guests no longer even notice them during their stay (Feickert et al. 2006). Today, electronic locks, fire protection systems, smoke detectors and closed-circuit televisions (CCTVs) are already installed in a large number of accommodation facilities (Okumus 2010). Chan and Lam (2013) indicated that tourists distinguish five security measures as essential that ensure their security in hotels: a well equipped fire prevention systems in accordance with local regulations, an emergency plan, an emergency lighting system, a 24-h uniformed security guard and the regular testing of the hotel security systems. DeFranco and Morosan (2017) added that currently connecting a traveler's mobile device to a hotel's network was also often seen by tourists as an essential security measure in hotels. Meanwhile, hotel managers consider the most important security measures to be closed-circuit television systems for hotel public areas, emergency lighting systems and the application of a guest key to activate the lifts to guest floors (Chan and Lam 2013). Henderson et al. (2010) added that more and more often, the accommodation facilities also use detectors (e.g., metal detectors and motion detectors), while Batterman and Fullerton (2002) and Feickert et al. (2006) additionally recommended technologies for monitoring the area. However, among the "hard" security measures, the literature usually recommends armed protection in or around the hotel (Chan and Lam 2013; Paraskevas 2013; Kiliçlara et al. 2018).

As indicated by AlBattat and Som (2013), there are various types of danger that a tourist may encounter at an accommodation facility. Thus, it is difficult to select the most appropriate security 
measures. Ghazi (2015) created the most complete and comprehensive list of security measures, formulating a set of 50 such measures. He divided them into the following types: detectors, emergency preparedness, medical preparedness, staff security, guestroom security, pool and beach, access control and information and cyber security (Ghazi 2015). The literature review on the security measures used at accommodation facilities is presented in Table 1.

Table 1. Literature review of the range of security measures used at accommodation facilities.

\begin{tabular}{|c|c|c|c|c|c|}
\hline \multirow[b]{2}{*}{ Proposed Security Measures } & \multicolumn{5}{|c|}{ Source } \\
\hline & $\begin{array}{l}\text { (Hilliard and } \\
\text { Baloglu } \\
\text { 2008) }\end{array}$ & $\begin{array}{l}\text { (Chan and } \\
\text { Lam 2013) }\end{array}$ & $\begin{array}{l}\text { (Singh } \\
\text { 2014) }\end{array}$ & $\begin{array}{c}\text { (Monitoring \& } \\
\text { Compliance Unit } \\
\text { Tourism Authority 2014) }\end{array}$ & $\begin{array}{l}\text { (Chauhan } \\
\text { and Negi } \\
\text { 2018) }\end{array}$ \\
\hline Well lit and marked emergency exits & + & + & + & & \\
\hline Hotel located in a low-crime area & + & & & & \\
\hline 24-h security staff & + & + & & + & + \\
\hline Smoke detectors & + & + & + & & \\
\hline Sprinkler system & + & + & + & & \\
\hline $\begin{array}{c}\text { Audible and visual fire alarms on } \\
\text { guest floors }\end{array}$ & + & + & + & & + \\
\hline Electronic key cards for guest rooms & + & + & & + & \\
\hline $\begin{array}{l}\text { Audible and visual fire alarms in } \\
\text { public areas }\end{array}$ & + & & + & & \\
\hline $\begin{array}{l}\text { Guest rooms located along } \\
\text { interior corridors }\end{array}$ & + & & & & \\
\hline Controlled after-hours access to hotel & + & & & + & \\
\hline $\begin{array}{l}\text { Staff training in cardiopulmonary } \\
\text { resuscitation (CPR), first-aid }\end{array}$ & + & & & & \\
\hline $\begin{array}{c}\text { Training program for staff action } \\
\text { in crises }\end{array}$ & + & & & & \\
\hline Security cameras in public areas & + & & & & \\
\hline In-room safety materials for guests & + & & & + & \\
\hline $\begin{array}{l}\text { Written policies for assisting the } \\
\text { people with disabilities guests } \\
\text { in emergencies }\end{array}$ & + & & & & \\
\hline Written security plans & + & & & & + \\
\hline $\begin{array}{l}\text { Automated external defibrillator } \\
\text { (AED) on-site }\end{array}$ & + & + & + & & + \\
\hline Back-up electrical generator & + & + & + & & + \\
\hline $\begin{array}{l}\text { Parking facility connected to } \\
\text { hotel building }\end{array}$ & + & & & & \\
\hline $\begin{array}{l}\text { Safety videos playing on in-room } \\
\text { guest televisions }\end{array}$ & + & & & & \\
\hline Employee photo ID & & + & + & & + \\
\hline Lifeguard & & + & + & & \\
\hline Safe deposit boxes & & + & + & & + \\
\hline Closed-circuit televisions (CCTVs) & & + & + & + & + \\
\hline $\begin{array}{l}\text { Clearly marked fire exits and } \\
\text { extinguishers }\end{array}$ & & + & & & \\
\hline $\begin{array}{l}\text { Deadbolt locks, primary locks and } \\
\text { one-way peepholes to guest } \\
\text { room doors }\end{array}$ & & + & & & \\
\hline $\begin{array}{l}\text { Private Automated Branch Exchange } \\
(\mathrm{PABX}) \text { systems for voice recording }\end{array}$ & & + & & & \\
\hline X-ray machines for luggage scanning & & + & + & & \\
\hline Communication systems & & + & + & & \\
\hline Metal detector at entrance & & + & + & & \\
\hline
\end{tabular}


Table 1. Cont.

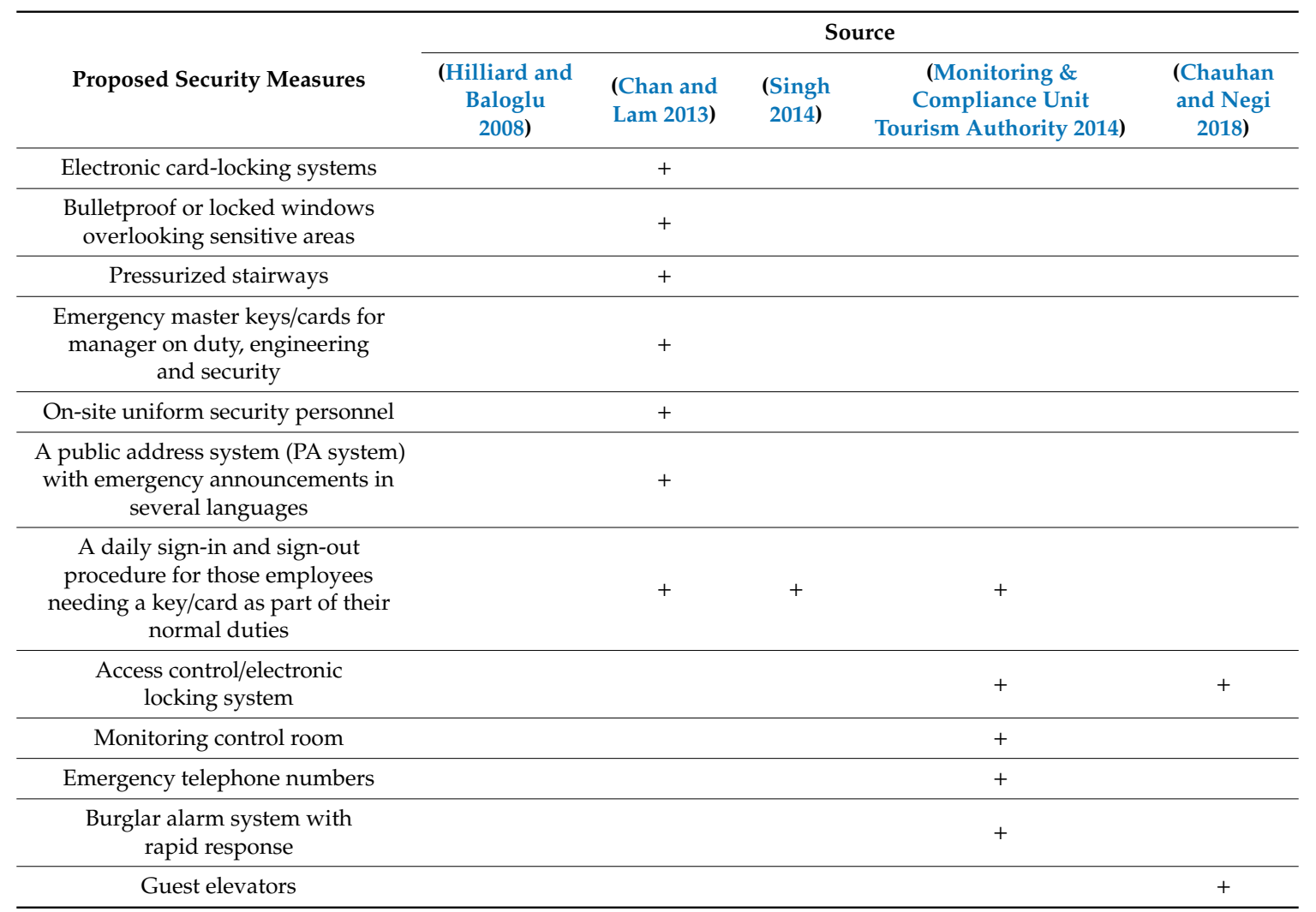

Source: based on (Hilliard and Baloglu 2008; Chan and Lam 2013; Singh 2014; Monitoring \& Compliance Unit Tourism Authority 2014; Ghazi 2015).

\section{Materials and Methods}

The aim of this article was to assess whether the type of accommodation facility, as measured by the star-rating system, which theoretically demonstrates a standard of quality and amenities, provided a higher level of security for the clients of accommodation facilities, measured by the number of security measures applied in them. It was decided to examine whether the level of concentration of security measures at the accommodation facilities was treated by the accommodation facilities as a factor of their competitiveness. An additional task was to assess whether the number of installed security measures correlated with the prices offered to tourists by the examined facilities. This additional objective will allow to check whether the security measures and their number have an impact on the prices of services, and thus additionally confirm or deny the importance of security in the strategy of the owners of tourist facilities. In order to achieve this goal, the authors decided to examine accommodation facilities in two well known tourist destinations in Central and Eastern Europe, located at the seaside, which additionally provided harbor services, i.e., one in Poland and one in Lithuania. These tourist destinations were two cities: Świnoujście (Poland) and Klaipèda (Lithuania). Świnoujście and Klaipeda can be described as harbor and tourist towns. In both cities there are provisions for the development of recreational, active, health, cultural and military tourism. Many tourists travel by ferry, because there are excellent connections to many cities and tourists frequently visit these destinations. Besides, in both countries these are very popular and well known tourist destinations. They are typical cities located near the Baltic Sea. For this reason, the most important natural hazard that could affect tourists were floods (storm, congestion), a low level of the Baltic Sea (threat to shipping), the icing of the Baltic Sea and dangerous atmospheric phenomena (thunderstorms, hail, air trumpets, strong winds and snowfall) (Ciupak 2010). It should also be noted that according to the World Risk Map (Drum Cussac 2019), Poland and Lithuania were among the countries with low levels of the following risks: security risks (including petty and violent crime, civil conflicts, protests, strikes and terrorism), 
political risks (including government stability, levels of corruption, political interference and sanctions), medical risks (including presence of diseases, standard of medical facilities, access to water and availability of pharmaceuticals), environmental risks (including proximity to seismic activity, frequency of storms, presence of manmade ordnance such as landmines and climatic hazards) and infrastructural risks (including road safety and standards, provision of utilities such as electricity, cyber-crime and aviation security and standards). Therefore, when selecting the security measures to be analyzed and comparing the security measures in both countries, only those related to threats that were present in both countries and those in the Baltic Sea region were taken into account.

All hotels and other accommodation facilities not subject to the star-rating system providing accommodation services on the territories of these cities (guesthouses, villas, holiday resorts, B\&Bs, hostels, motels, holiday complexes) were analyzed. Facilities not having at least two separate rooms available for rent by separate households, i.e., apartments and private accommodation, were excluded from the analysis. The database of the accommodation facilities in these locations was online travel and related services from Booking.com. It is worth noting that websites such as global travel website Booking.com (Aksoy and Ozbuk 2017), hotel review website TripAdvisor (Banerjee and Chua 2016) and online marketplace Airbnb (Blal et al. 2018) provided us with databases increasingly used in the literature to analyze the situation in the tourism sector and tourist preferences. This indicated their research credibility. As the number of visitors and bookings on these portals shows, people trust the information provided on these sites, as well as offering customer reviews.

The number of accommodation facilities operating in the examined resorts was determined on 11 March 2020. The total number of accommodation facilities analyzed was 85 for Świnoujście and 56 for Klaipeda. Table 2 shows the structure of the accommodation facilities by type of establishment, measured the star-rating system (number of stars).

Table 2. Number of establishments by the type of accommodation facility.

\begin{tabular}{cccccccccccc}
\hline City & \multicolumn{3}{c}{ Świnoujście } & \multicolumn{5}{c}{ Klaipèda } \\
\hline $\begin{array}{c}\text { Type of Accommodation } \\
\text { Facility }\end{array}$ & $\begin{array}{c}\text { Other } \\
\text { Facilities }\end{array}$ & Hotels & $\begin{array}{c}\text { Other } \\
\text { Facilities }\end{array}$ & Hotels \\
\hline *tar-rating system * & $\mathbf{0}$ & $\mathbf{2}$ & $\mathbf{3}$ & $\mathbf{4}$ & $\mathbf{5}$ & $\mathbf{0}$ & $\mathbf{2}$ & $\mathbf{3}$ & $\mathbf{4}$ & $\mathbf{5}$ \\
\hline Number of objects & 64 & 2 & 13 & 3 & 3 & 33 & 1 & 14 & 8 & 0 \\
\hline The star-rating system applies only to hotels. Other accommodation facilities are not subject to this system.
\end{tabular}

The subject of this study was security measures installed in the accommodation facilities, and the source of information about them was Booking.com. Before the selection of the security measures was made, the types of threats, and thus risks, present in the regions and countries where the cities are located were first identified (the analysis of these threats was already presented in this section of the article. This was done using the European Risk Map (Drum Cussac 2019) and the information provided on the websites of the Ministry of Foreign Affairs of both analyzed countries). In Lithuania and Poland, the accommodation facilities we examined were subject to the legal regulations in force in these countries, i.e., fire, sanitary and construction laws. In addition, there were supplementary regulations to ensure the greater safety of these facilities. Moreover, depending on the type of facility and services provided, the legal regulations specify the required security measures (e.g., when there is a SPA center, activity space, swimming pool, baths or other additional services, additional ordinances apply). In Poland, according to the announcement of the Minister of Sport and Tourism (Minister of Sport and Tourism 2017) (including hotels and motels, boarding houses, camping sites, holiday homes, youth hostels and hostels), the required equipment for hotels is determined by the number of "stars" and other facilities of the establishment. In Lithuania, such a basic legal act is the regulation of the Minister of Economy and Innovation (Minister of Economy and Innovation 2019) concerning the approval of the relevant classification requirements for appropriate types of accommodation (including hotels and motels, campsites, guest houses). 
Then, based on the list of safety measures appropriate for these risks presented in the literature (Ghazi 2015; Hilliard and Baloglu 2008; Chan and Lam 2013; Singh 2014; Monitoring \& Compliance Unit Tourism Authority 2014; Chauhan and Negi 2018), the safety measures analyzed in this article were selected. Due to the large number of such measures, the following security measures were identified, which were most often proposed by the literature (see Table 1). The principle was that they should represent all eight dimensions of the security measures proposed by Ghazi (2015). As a result, the authors selected 13 such security measures in the article. These were fire extinguishers, CCTV outside property, CCTV in common areas, Security alarm, 24-h security, airport shuttle/airport drop off, lift, private parking, allergy-free room, 24-h front desk, safe deposit box, concierge service and smoke alarms. All of the security measures analyzed in this article were the so-called "soft measures", i.e., those that the literature recommends as preferred by the owners not to create a sense of fear among tourists.

Each of the accommodation facilities was analyzed in terms of the number of security measures installed out of the 13 listed above. For this purpose, the percentage of occurrence of these measures at the establishments was calculated by the type of establishment and the type of security measure (as a weighted average) and their degree of concentration. The criterion for classifying the type of accommodation facilities was the star-rating system, whereas when assessing the scale of occurrence of security measures by their type, the number of the given types of facilities was a weighting. The Herfindahl-Hirscham Index (HHI) was used to calculate the concentration of security measures at the establishments concerned according to the formula:

$$
\mathrm{HHI}=\sum_{\mathrm{i}=1}^{n}\left(100 \cdot \mathrm{U}_{\mathrm{i}}\right)^{2}
$$

where $U_{i}$ indicates the relative share of the i-th security measure in the establishments.

The application of this indicator was due to the fact that the aim of the article was to assess the level of security in accommodation establishments, measured by the number of security measures applied in them. The concentration index used and the results obtained will help to obtain information in two areas. Firstly, knowledge will be obtained about the level of concentration of security measures, i.e., whether one, two or more security measures predominate in the accommodation facilities. In this way, in addition to the information on the number of security measures used at the accommodation facilities, the results will show the scale of their use, i.e., the percentage of individual security measures in the security systems. Secondly, this analysis will allow one to assess the level of concentration of security measures both by the type of security measures and by the type of accommodation facility (i.e., how the type of accommodation facility differentiates the scale of use of security measures).

In the literature, the Herfindahl-Hirscham Index has to date been used most often to assess the impact of consolidation processes on the level of the competitiveness in a given market, and until 1950 the HHI was mainly used by economists to measure income distribution and inequality. Methodologically, this measure is essentially equivalent to the Simpson diversity index, which is now widely used in many fields of science. In addition to economics, where this measure is widely applied, it was also used in the literature, e.g., in the energy sector to assess the cost of energy security, (Jun et al. 2009) in ecology (Fath 2018), in urbanism to assess the relationship between industrial diversity and population growth (Wang et al. 2020), in physics when calculating the inverse participation ratio (Yue et al. 2016), in molecular biology to access the results of human creative thinking (Sankaran and Hankey 2017), when calculating the effective number of parties index (Boydstun et al. 2014), in portfolio theory to assess portfolio diversification (Lovett 2009; Woerheide and Persson 1993) and to measure the diversity of user behavior (Poulain and Tarissan 2020), or in informatics and management through the use an artificial neural network and assessing the relevance of the relationship between competition in the product market and the investment of the companies and monitoring market power (Kordanuli et al. 2017). 
The authors, on the other hand, decided to use this measure to determine whether the accommodation facilities used multiple security measures, only a few, or just one. It was used to assess the level of security at the accommodation facilities, measured by the number of security measures installed in them. The low values of this indicator, i.e., below 1500, indicated a low concentration of the security measures in accommodation facilities (of which less than 1000 were with very low concentration), or the fact that many measures were applied with the lack of domination of one or several specific such measures. High values of this indicator, i.e., above 2500, indicated a high or very high degree of concentration. In this study, this would mean a situation where accommodation facilities mainly use several security measures or that the same security measures would be everywhere.

Hypothetically, an increasingly higher rating (in the star-rating system) should mean an increasingly higher quality of services and facilities and thus, by definition, a higher level of security. According to the literature (Israeli 2002; Minazzi 2010), the star-rating system affects the price of accommodation services. Therefore, it can be assumed that there is also a positive correlation between the price of the accommodation facility and the level of security, measured by the number of security measures applied by the accommodation facilities. Therefore, in order to confirm the relationship between the star-rating system and the level of security, it was also examined whether there was a statistical relationship between the price of the accommodation facilities in the examined resorts and the number of security measures applied at the accommodation facilities. The correlation coefficient was used for this purpose.

\section{Results}

First of all, it was examined which of the security measures were in the accommodation facilities of the analyzed resorts and what was the frequency of their occurrence by the type of facility. The data on the scale of the occurrence of security measures and for each type of security measure at the accommodation facilities, divided by the age-rating system and the weighted average frequency of these security measures at the accommodation facilities of the examined tourist destinations, are presented in Table 3.

Table 3. Accommodation facilities where the security measures are installed (as a percentage of the total number of establishments of this type (in \%).

\begin{tabular}{ccccccccccccc}
\hline Itemization & \multicolumn{3}{c}{ Świnoujście } & \multicolumn{7}{c}{ Klaipèda } \\
\hline $\begin{array}{c}\text { Security Measures/Facility } \\
\text { Type (Star-Rating System) }\end{array}$ & $\mathbf{0}$ & $\mathbf{2}$ & $\mathbf{3}$ & $\mathbf{4}$ & $\mathbf{5}$ & Total & $\mathbf{0}$ & $\mathbf{2}$ & $\mathbf{3}$ & $\mathbf{4}$ & $\mathbf{5}$ & Total \\
\hline Fire extinguishers (FE) & 56 & 50 & $\mathbf{6 1}$ & $\mathbf{3}$ & $\mathbf{6 7}$ & 56 & 30 & 100 & 71 & 75 & - & 48 \\
\hline CCTV outside property (OP) & 59 & 50 & 61 & 33 & 67 & 59 & 24 & 100 & 71 & 75 & - & 45 \\
\hline CCTV in common areas (CA) & 47 & 50 & 46 & 33 & 67 & 47 & 18 & 100 & 71 & 75 & - & 41 \\
\hline Security alarm (SA) & 28 & 50 & 54 & 33 & 67 & 34 & 15 & 0 & 64 & 25 & - & 29 \\
\hline 24-h security (SE) & 6 & 50 & 31 & 33 & 67 & 14 & 9 & 0 & 29 & 37 & - & 18 \\
\hline Airport shuttle/airport drop & 31 & 100 & 46 & 67 & 100 & 39 & 30 & 0 & 79 & 100 & - & 52 \\
\hline off (AS) & 42 & 50 & 85 & 100 & 100 & 53 & 30 & 0 & 43 & 87 & - & 41 \\
\hline Guest elevators (GE) & 64 & 50 & 77 & 33 & 100 & 66 & 82 & 100 & 86 & 75 & - & 82 \\
\hline Private parking (PP) & 8 & 50 & 8 & 0 & 0 & 8 & 0 & 0 & 21 & 12 & - & 7 \\
\hline Allergy-free room (AF) & 34 & 100 & 77 & 100 & 100 & 47 & 30 & 100 & 79 & 100 & - & 54 \\
\hline 24-h front desk (FD) & 37 & 50 & 85 & 67 & 100 & 48 & 15 & 0 & 64 & 100 & - & 39 \\
\hline Safe deposit box (DB) & 2 & 50 & 23 & 0 & 0 & 6 & 0 & 0 & 0 & 37 & - & 5 \\
\hline Concierge service (CS) & 34 & 0 & 61 & 33 & 67 & 39 & 45 & 100 & 71 & 75 & - & 57 \\
\hline Smoke detectors (SD) & $\mathbf{3 4}$ & $\mathbf{5 4}$ & $\mathbf{5 5}$ & $\mathbf{4 4}$ & $\mathbf{7 0}$ & & $\mathbf{2 5}$ & $\mathbf{4 6}$ & $\mathbf{5 8}$ & $\mathbf{6 7}$ & - & \\
\hline $\begin{array}{c}\text { Weighted average } \\
\text { frequency of occurrence }\end{array}$ & $\mathbf{3 4}$ & & & & & & & & &
\end{tabular}


The results of the analysis showed that all of the tested security measures were applied at the establishments of the studied tourist destinations, however, only four out of the 13 security measures were installed in at least half of the establishments located there. In Świnoujście these were fire extinguishers, CCTV outside property, guest elevators, private parking, and in Klaipeda these were the transfer to/from the airport, private parking, 24-h front desk and smoke detectors. In both cities, the most frequently installed security measure was the car parking facility connected to the hotel building (65.9\% of the analyzed facilities in Świnoujście and $82.1 \%$ in Klaipeda), which was an element of convenience for the customers. On the other hand, the security measures whose installation required the employment of additional staff to operate them, i.e., concierge service (5.9\% and 5.4\% respectively) and 24 -h security (14.1\% and 17.9\%, respectively), or were related to health, e.g., allergy-free room $(8.2 \%$ and $7.1 \%$, respectively), were the least frequent.

However, when analyzing in detail the types of security measures by the type of accommodation facility, it should be noted that there were similar trends in both locations. In Swinoujście, the following safety measures were most frequently used in the other accommodation facilities, i.e., those not assessed according to the star-rating system (more than half of the facilities installed them): private parking (PP), CCTV outside property (OP) and fire extinguishers (FE). The least frequently found ones were the concierge service (CS), 24-h security (SE) and the allergy-free room (AF) (i.e. less than $10 \%$ of accommodation facilities without "stars" installed them). The remaining security measures were applied only by $28 \%-42 \%$ of the facilities. In Klaipeda, on the other hand, more than half of the facilities had only one security measure installed, i.e., PP, while less than $10 \%$ of the entities applied (as in Świnoujście) the following security measures: CS, SE and AF. Meanwhile, in hotels with two "stars" in Świnoujście, most of the security measures were used, of which often airport shuttle/airport drop off (AS) and a 24-h front desk (FD) (these are security measures that also affect the comfort of customer services), and rarely smoke detectors (SD). However, in Klaipeda more than $50 \%$ of the facilities had installed FE, OP, CCTV in common areas (CA), PP, FD, SD (i.e., security measures that also affect the comfort of customer services and those related to monitoring), and less than $10 \%$ had installed security alarms (SAs), SE, AS, guest elevators (GE), AF, safe deposit box (DB) and CS. In hotels with three "stars" in Świnoujście, eight security measures were often used (FE, OP, SA, GE, PP, FD, DB, SD) and rarely AF. Similar security measures are often used in Klaipèda, i.e., FE, OP, CA, AS, FD, $\mathrm{DB}, \mathrm{SD}$, but rarely CS. This means that so-called health security measures were rarely used, and often it was those related to monitoring and detectors. On the other hand, in facilities with four and five "stars", the trends were similar to those in facilities with three "stars", but the higher the number of 'stars', the more the operators applied these security measures.

These conclusions were also confirmed by the results of the concentration analysis (Table 4), which showed that the HHI value in both localities was very high for AS and relatively high for FE, OP, CA, GE, FD and DB, while low for SE, AF and CS. It was also found that in most hotels more security measures were installed (the level of security was higher) than in other accommodation facilities (i.e., those that are not subject to the star-rating system).

Since the above results and their graphic illustration indicate a linear relationship between the number of security measures and the type of accommodation facility, the relationship was additionally analyzed using a correlation coefficient. The analysis of the correlation between the number of stars owned by the accommodation facility and the level of security indicated that there was a positive correlation for both locations (for Świnoujście 0.7153 at $p<0.1743$, and for Klaipeda 0.9826 at $p<$ 0.0174). It indicated that in Świnoujście there was a strong positive correlation between these variables with a probability of $82.5 \%$, and in Klaipeda 0.9826 with a probability of $98.3 \%$ with a very strong positive correlation. 
Table 4. Level of concentration of the security measures at the accommodation facilities as measured by the Herfindahl-Hirscham Index.

\begin{tabular}{ccc}
\hline Security Measures & Świnoujście & Klaipėda \\
\hline Fire extinguishers (FE) & 3216.4 & 2798.8 \\
\hline CCTV outside property (OP) & 3488.5 & 2604.0 \\
\hline CCTV in common areas (CA) & 2235.1 & 2452.5 \\
\hline Security alarm (SA) & 1293.9 & 1257.7 \\
\hline 24-h security (SE) & 429.1 & 453.7 \\
\hline Airport shuttle/airport drop off (AS) & 1806.2 & 3513.1 \\
\hline Guest elevators (GE) & 3199.8 & 2094.1 \\
\hline Private parking (PP) & 4446.0 & 6763.7 \\
\hline Allergy-free room (AF) & 113.8 & 137.1 \\
\hline 24-h front desk (FD) & 2735.9 & 3691.6 \\
\hline Safe deposit box (DB) & 2722.5 & 2597.0 \\
\hline Concierge service (CS) & 142.1 & 200.9 \\
\hline Smoke detectors (SD) & 1665.0 & 3475.2 \\
\hline
\end{tabular}

The studies also indicated that within the types of accommodation facilities concerned, it could not be claimed that there was a high level of concentration of individual security measures and that different security measures were applied. Table 5 shows the level of concentration of the security measures in the different types of establishments (level of concentration of the security measures by the type of accommodation facility).

Table 5. Level of concentration of the security measures by the type of accommodation facility measured by Herfindahl-Hirscham Index.

\begin{tabular}{cccccccccccc}
\hline Itemization & \multicolumn{4}{c}{ Świnoujście } & \multicolumn{5}{c}{ Klaipèda } \\
\hline $\begin{array}{c}\text { Facility Type by } \\
\text { Star-Rating System }\end{array}$ & $\mathbf{0}$ & $\mathbf{2}$ & $\mathbf{3}$ & $\mathbf{4}$ & $\mathbf{5}$ & $\mathbf{0}$ & $\mathbf{2}$ & $\mathbf{3}$ & $\mathbf{4}$ & $\mathbf{5}$ \\
\hline HHI & 1007.9 & 918.4 & 903.0 & 1141.9 & 946.5 & 1273.5 & 1666.7 & 915.2 & 906.1 & - \\
\hline
\end{tabular}

The HHI values for each type of accommodation facility in the analyzed cities were quite low (in Świnoujście 903.0-1141.9, and in Klaipèda 906.1-1273.5). While in Poland the concentration was low or very low everywhere, in Klaipeda there was a very low HHI in the facilities with more stars, and in facilities with a lower service quality ( $0-2$ "stars" in the star-rating system) there was a medium level of concentration.

So far, the research results showed that there was a positive correlation between the number of stars owned by the accommodation facility (in the star-rating system) and the safety and security level measured by the number of security measures installed in the facility. These results mean that hotels with more services also incur higher costs for installing security measures. Therefore, in order to further interpret the results obtained to date, it was decided to check whether this had an impact on the prices of the accommodation services. Therefore, at the end of the study, an analysis of the relationship between the price of the accommodation in the facility and the number of security measures installed in the facility was performed. The analysis showed that there was no statistically significant correlation between the price of an accommodation in an accommodation facility and the number of security measures installed there. The correlation coefficient for Świnoujście was 0.2042 at $p<0.0624$; and for Klaipeda 0.0930 at $p<0.5036$. 


\section{Discussion}

In this article, the authors decided to examine whether the competitiveness of accommodation facilities, i.e., the number of stars they have, which determines the standard of quality and facilities they have, resulted from the level of safety and security provided to the consumers of these services, measured by the number of security measures applied in them. The results of the research indicated that the accommodation facilities rarely applied all 13 security measures analyzed, but usually had at least a few security measures installed. This rule applied both to localities in Poland and Lithuania. Moreover, it was found that regardless of the type of the accommodation facility, different security measures were applied and were not concentrated only within a few selected measures, which was confirmed by the low HHI values. This would confirm the results indicated in the literature (see Table 1), where scientists in their research indicated a great number of security measures applied in the accommodation facilities and nowhere were they fully the same security measures.

In this article, the authors also stated that there was a relationship between the number of stars owned by an accommodation facility and the number of security measures applied. The more stars a facility had, the more security measures were installed. As Tefera and Govender (2015) indicated, the classification of hotels was needed to protect customers and help them choose the accommodation facility that best suited their needs and expectations. The results of the research conducted by the authors therefore indicated that the classification of hotels and other accommodation facilities can also be used to assess in which accommodation facility there is more emphasis on security and more security measures are installed. However, as indicated by Go and Pine (2005), hotel-rating systems vary considerably from country to country, and the criteria used often reflect local cultural differences. This means that the research carried out in this article must be done separately for each country or geographical region, and in this particular case we can only talk about the dependencies that exist in these specific locations in Central and Eastern Europe.

The literature indicates that the quality of the services and facilities provided, reflected by the star-rating system, affects the price of accommodation services (Israeli 2002; Minazzi 2010). However, the analysis carried out by the authors showed that there was no statistically significant correlation between the price of accommodation in an accommodation facility and the number of security measures installed there. This allowed us to put forward a thesis that the level of guaranteed security by the accommodation facilities in the studied cities was not a criterion of what prices will be charged to the clients of the accommodation facilities. Therefore, Minazzi (2010) thesis that the number of stars was a price indicator rather than a quality indicator cannot be accepted. In the locations analyzed in the article, the conclusion was different, namely that the number of stars was an indicator of quality and of the level of safety and security provided to the customers rather than an indicator of the price to be offered to tourists.

\section{Conclusions}

The article assesses whether security measures are or can be treated by accommodation facilities as a factor of their competitiveness. A critical analysis of the literature indicated that safety and security are among the factors that tourists take into account when deciding on the choice of an accommodation facility and the tourist destination competitiveness. Moreover, people are willing to pay more for an accommodation facility with safety and security certificates. Therefore, it was decided to investigate whether the type of facility measured by the star-rating system was also a measure of security of the accommodation facilities. The literature has shown that the owners of tourist facilities prefer "soft" security measures to "hard" ones, as the latter are too expensive and can create an atmosphere of anxiety among tourists. Therefore, the security measures analyzed in this article, according to the recommendations of the literature, belonged to the group of so-called "soft" measures. The Herfindahl-Hirscham Index was used for this analysis, which is a novelty in the literature, as this measure has to date been used to assess consolidation processes to the level of competitiveness in a given market. 
The results of the research carried out in this article indicated that the accommodation facilities quite extensively had security measures installed. Similar security measures were applied at the accommodation facilities of both cities, which was also due to the fact that they are located in countries of similar risks and both are in the same region, i.e., the Baltic Sea region. In both of the studied towns, the most frequently installed security measure was a car park facility connected directly to the hotel building, while the rarest ones were those related to the need to employ additional staff, i.e., concierge service and 24-h security, or those related to health, i.e., allergy-free rooms. It was found that the accommodation facilities in the analyzed localities applied various security measures and except for fenced parking facilities, it was difficult to talk here about the security measures preferred by all the accommodation facilities. Approximately half of the facilities were found to use such security measures as detectors and technologies for monitoring the area, which was in line with the results of the Henderson et al. (2010), Batterman and Fullerton (2002) and Feickert et al. (2006) studies, which indicated that these security measures were increasingly being used in the accommodation facilities. However, both localities here differed in the type of security measure, as in the tourist destination in Poland usually used fire extinguishers, CCTV outside property and guest elevators, while in destination in Lithuania it was mainly the transfer to/from the airport, 24-h front desk and smoke detectors. The conclusion of the similarity of these cities was confirmed by the concentration rates of the security measures, both of which were quite low (in Świnoujście 903.0-1141.9 and in Klaipèda 906.1-1273.5). Some differences existed only in the case of Klaipeda, where the level of concentration was at an average level in facilities with lower service quality ( $0-2$ "stars" in the star-rating system). Moreover, it was also found that the higher the quality of service declared by an establishment, as measured by the star-rating system, the lower the concentration of security measures, estimated as low HHI values. These results mean that more security measures were installed in such establishments. It can therefore be concluded that the level of security is considered by the establishments as a criterion for the quality of the services they provide and therefore a factor for their competitiveness. It was also found that the amount of security measures installed by the establishments did not affect the price of their services. Therefore, the level of guaranteed security was not a criterion in the analyzed locations as to what prices would be charged to customers of the accommodation facilities. This was influenced by factors other than the level of security. It was also a suggestion for the owners of such facilities not to treat the level of security offered as a pricing factor, but rather as an element of service quality that could be used in advertising their business. The results and conclusions obtained in this article should also help the owners of accommodation facilities to improve the quality of their services. They are informed about how many safety measures and which of them they should install in their accommodation facilities if they want to remain competitive in the market or what they should do to improve their services to obtain more "stars". On the other hand, the future facilities find out what security investments they have to make in order to enter the market. There is therefore space for further research in this topic. It can therefore be presumed, following DeFranco and Morosan (2017), that some security measures are seen by tourists as a security requirement in accommodation facilities and therefore the owners of such facilities do not regard the fact that they have installed these security measures as a price factor.

Author Contributions: Conceptualization, R.N. and B.Ž.; methodology, R.N.; software, R.N.; validation, R.N. and B.Ž.; formal analysis, R.N. and B.Ž.; investigation, R.N. and B.Ž.; resources, B.Ž.; data curation, R.N. and B.Ž.; writing—original draft preparation, R.N. and B.Ž.; writing—review and editing, R.N. and B.Ž.; visualization, R.N. and B.Ž.; supervision, R.N. and B.Ž.; project administration, R.N. and B.Ž.; funding acquisition, R.N. and B.Ž. All authors have read and agreed to the published version of the manuscript.

Funding: The project is co-financed within the framework of the program of the Minister of Science and Higher Education under the name "Regional Excellence Initiative" in the years 2019-2022; project number 001/RID/2018/19; the amount of financing PLN 10,684,000.00.

Conflicts of Interest: The authors declare no conflict of interest. 


\section{References}

Aksoy, Safak, and Meltem Yetkin Ozbuk. 2017. Multiple criteria decision making in hotel location: Does it relate to postpurchase consumer evaluations? Tourism Management Perspectives 22: 73-81. [CrossRef]

AlBattat, Ahmad Rasmi, and Ahmad Puad Mat Som. 2013. Emergency Preparedness for Disasters and Crises in the Hotel Industry. SAGE Open Journals 3: 10. [CrossRef]

Baber, Ruturaj, Rahul Kaurav, Pratap Singh, and Robert L. Williams, Jr. 2015. How travelers differ in their preferences regarding hotel selection: Empirical evidence from travelers in India. Asian Journal of Tourism and Hospitality Research 8-9: 15-26.

Banerjee, Snehasish, and Alton Y. K. Chua. 2016. In search of patterns among travellers' hotel ratings in TripAdvisor. Tourism Management 53: 125-31. [CrossRef]

Batterman, Robert L., and John F. Fullerton. 2002. Collective bargaining after September 11: What about job security and workplace security? Cornell Hotel and Restaurant Administration Quarterly 43: 93-108. [CrossRef]

Blal, Inès, Manisha Singal, and Jonathan Templin. 2018. Airbnb's effect on hotel sales growth. International Journal of Hospitality Management 73: 85-92. [CrossRef]

Boydstun, Amber E, Shaum Bevan, and Herschel F. Thomas. 2014. The Importance of Attention Diversity and How to Measure It: Measuring Attention Diversity. Policy Studies Journal 42: 173-96. [CrossRef]

Chan, Eric S. W., and Doris Lam. 2013. Hotel safety and security systems: Bridging the gap between managers and guests. International Journal of Hospitality Management 32: 202-16. [CrossRef]

Chauhan, Abhishek Shukla Ankit, and Pradeep Negi. 2018. Safety and security measures adopted by the hotels and their impact on customer relationship management. International Journal of Research-Granthaalayah 6: 118-25.

Chen, Joseph S., and Dogan Gursoy. 2001. An investigation of tourists' destination loyalty and preferences. International Journal of Contemporary Hospitality Management 13: 79-85. [CrossRef]

Chu, Raymond K. S., and Tat Choi. 2000. An importance-performance analysis of hotel selection factors in the Hong Kong hotel industry: A comparison of business and leisure travellers. Tourism Management 21: 363-77. [CrossRef]

Ciupak, Maurycy. 2010. Zagrożenia naturalne dla polskich miast portowych w świetle informacyjnego zabezpieczania procesu zarzadzania kryzysowego [Natural hazards for the Polish port cities in the aspect of information security process of the crisis management]. Rocznik Bezpieczeństwa Morskiego 4: 157-72.

Croes, Robertico, Jorge Ridderstaat, and Valeriya Shapoval. 2020. Extending tourism competitiveness to human development. Annals of Tourism Research 80: 102825. [CrossRef]

DeFranco, Agnes, and Cristian Morosan. 2017. Coping with the risk of internet connectivity in hotels: Perspectives from American consumers traveling internationally. Tourism Management 61: 380-93. [CrossRef]

Drum Cussac. 2019. Most Dangerous Countries in the World 2019 (World Risk Map). Available online: https://drum-cussac.com/blog/world-risk-map/ (accessed on 4 April 2020).

Fang, Lei, Hengyun Li, and Mimi Li. 2019. Does hotel location tell a true story? Evidence from geographically weighted regression analysis of hotels in Hong Kong. Tourism Management 72: 78-91. [CrossRef]

Fath, Brian D. 2018. Encyclopedia of Ecology, 2nd ed. Amsterdam: Elsevier.

Feickert, Julie, Rohit Verma, Gerhard Plaschka, and Chekitan S. Dev. 2006. Safeguarding your customers: The guest's view of hotel security [Electronic version]. Cornell Hotel and Restaurant Administration Quarterly 47: 224-44. [CrossRef]

Garg, Anshuland, and Jeetesh Kumar. 2017. The Impact of Risk Perception and Factors on Tourists' Decision Making for Choosing the Destination Uttarakhand/India. Journal of Tourism and Management Research 2: 144-60. [CrossRef]

Ghazi, Karam Mansour. 2015. Safety and Security Measures in Egyptian Hotels. Hotel E Business Management 4: 1-11.

Go, Frank M., and Ray Pine. 2005. Globalization Strategy in the Hotel Industry. London: Routledge.

Goffi, Gianluca, Marco Cucculelli, and Lorenzo Masiero. 2019. Fostering tourism destination competitiveness in developing countries: The role of sustainability. Journal of Cleaner Production 209: 101-15. [CrossRef]

Henderson, Joan C., Chew Shufen, Lee Huifen, and Lee Ling Xiang. 2010. Tourism and terrorism: A hotel industry perspective. Journal of Tourism, Hospitality $\mathcal{E}$ Culinary Arts 2: 33-46.

Henderson, Joan C. 2007. Tourism Crises: Causes, Consequences and Management. Amsterdam: Elsevier. 
Hilliard, Tyra W., and Seyhmus Baloglu. 2008. Safety and Security as Part of the Hotel Servicescape for Meeting Planners. Journal of Convention E Event Tourism 9: 15-34.

Howie, Luke John. 2005. There is nothing to fear but fear itself (and terrorists): Public perception, terrorism and the workplace. In 2005 Proceedings: Social Change in the 21st Century. Edited by Chanel Bailey and Karen Barnett. Brisbane: Centre for Social Change Research, QUT, vol. 1, pp. 1-11.

Israeli, Aviad A. 2002. Star rating and corporate affiliation: Their influence on room price and performance of hotels in Israel. Hospitality Management 21: 405-24. [CrossRef]

Jun, Eunju, Wonjoon Kim, and Soon Heung Chang. 2009. The analysis of security cost for different energy sources. Applied Energy 86: 1894-901. [CrossRef]

Kılıçlara, Arzu, Ahmet Uşakli, and Tayfun Ahmet. 2018. Terrorism prevention in tourism destinations: Security forces vs. civil authority perspectives. Journal of Destination Marketing \& Management 8: 232-46.

Kim, Hong-Bumm, Dong-Soo Lee, and Sunny Ham. 2013. Impact of hotel information security on system reliability. International Journal of Hospitality Management 35: 369-79. [CrossRef]

Kordanuli, Bojana, Lidija Barjaktarović, Ljiljana Jeremić, and Meysam Alizamir. 2017. Appraisal of artificial neural network for forecasting of economic parameters. Physica A: Statistical Mechanics and its Applications 465: 515-9. [CrossRef]

Kôvári, Istvan, and Krisztina Zimányi. 2011. Safety and Security in the Age of Global Tourism (The changing role and conception of Safety and Security in Tourism). Applied Studies in Agribusiness and Commerce 5: 59-61. [CrossRef]

Kubickova, Marketa, Destan Kirimhan, and Hengyun Li. 2019. The impact of crises on hotel rooms' demand in developing economies: The case of terrorist attacks of 9/11 and the global financial crisis of 2008. Journal of Hospitality and Tourism Management 38: 27-38. [CrossRef]

Lee, Kuo-Jung, Su-Lien Lu, and You Shih. 2018. Contagion Effect of Natural Disaster and Financial Crisis Events on International Stock Markets. Journal of Risk and Financial Management 11: 1-25.

Lovett, William Anthony. 2009. Banking and Financial Institutions Law in a Nutshell, 7th ed. Saint Paul: West Academic Press.

Minazzi, Roberta. 2010. Hotel Classification Systems: A Comparison of International Case Studies. Acta Universitatis Danubius: Oeconomica 6: 65-88.

Minister of Economy and Innovation. 2019. Regulation of the Minister of Economy and Innovation of the Republic of Lithuania Dated 8 August 2019 Concerning the Approval of Classification Requirements for Relevant Types of Accommodation Services. No. 4-462. Available online: https://e-seimas.lrs.lt/portal/legalAct/lt/ TAD/bc916160ba1311e982dae1db4290b1a9?jfwid=-td2hez03t (accessed on 20 March 2020).

Minister of Sport and Tourism. 2017. Announcement of the Minister of Sport and Tourism Dated 26 October 2017 on the Publication of the Consolidated text of the Regulation of the Minister of Economy and Labour on Hotel Facilities and Other Facilities Where Hotel Services Are Provided. Journal of Laws of 2017. Item 2166. Available online: http://prawo.sejm.gov.pl/isap.nsf/download.xsp/WDU20170002166/O/D20172166.pdf (accessed on 20 March 2020).

Monitoring \& Compliance Unit Tourism Authority. 2014. Safety and Security Measures-Tourist Accommodation. Available online: http://www.tourismauthority.mu/userfiles/Annex\%2013-SAFETY\% 20AND\%20SECURITY\%20MEASURES\%20FOR\%20ACCOMODATION(1).pdf (accessed on 10 March 2020).

Nagaj, Rafał, and Piotr Szkudlarek. 2019. The change in the perception of the state by students in Poland and Lithuania in the context of research on social capital. Economic Research-Ekonomska Istraživanja 32: 1298-319. [CrossRef]

OECD. 2020. OECD Interim Economic Assessment Coronavirus: The World Economy at Risk. Available online: http://www.oecd.org/berlin/publikationen/Interim-Economic-Assessment-2-March-2020.pdf (accessed on 10 March 2020).

Okumus, Fevzi. 2010. Safety. In International Encyclopedia of Hospitality Management. Edited by Abraham Pizam. Oxford: Elsevier Butterworth-Heinemann, p. 594.

Paraskevas, Alexandros. 2013. Aligning strategy to threat: A baseline anti-terrorism strategy for hotels. International Journal of Contemporary Hospitality Management 25: 140-62. [CrossRef]

Pizam, Abraham. 2010. Hotels as tempting targets for terrorism attacks. International Journal of Hospitality Management 29: 1. [CrossRef] 
Poulain, Rémy, and Fabien Tarissan. 2020. Investigating the lack of diversity in user behavior: The case of musical content on online platforms. Information Processing \& Management 57: 102169.

Rittichainuwat, Bongkosh N., and Goutam Chakraborty. 2012. Perceptions of importance and what safety is enough. Journal of Business Research 65: 42-50. [CrossRef]

Sankaran, Krithiga, and Alex Hankey. 2017. Experience information as the basis of mind: Evidence from human decision making. Progress in Biophysics and Molecular Biology 131: 369-76. [CrossRef]

Singh, Jaswinder. 2014. Safety \& Security Concerns in Hospitality Industry. International Journal of Management and Commerce Innovations 2: 1-5.

Survila, Arvydas, Edvinas Mikènas, and Brigita Žuromskaite. 2017. The Impact of Terrorism on the Tourism Sector of Lithuania. Montenegrin Journal of Economics 13: 101-18. [CrossRef]

Tefera, Orthodox, and Krishna Govender. 2015. Hotel Grading, Service Quality, Satisfaction and Loyalty-Proposing a Theoretical Model and Relationship. African Journal of Hospitality, Tourism and Leisure 4: 1-17.

Wang, Jian, Zhuqing Yang, and Xuepeng Qian. 2020. Driving factors of urban shrinkage: Examining the role of local industrial diversity. Cities 99: 102646. [CrossRef]

Wilhelmsson, Mats, and Jianyu Zhao. 2018. Risk Assessment of Housing Market Segments: The Lender's Perspective. Journal of Risk and Financial Management 11: 1-22.

Woerheide, Walt, and Don Persson. 1993. An Index of Portfolio Diversification. Financial Services Review 2: 73-85. [CrossRef]

World Tourism Organization. 2019. International Tourism Highlights, 2019 Edition. Madrid: UNWTO, Available online: https://www.e-unwto.org/doi/pdf/10.18111/9789284421152 (accessed on 10 March 2020). [CrossRef]

Yang, Yang, Kevin K. F. Wong, and Tongkun Wang. 2012. How do hotels choose their location? Evidence from hotels in Beijing. International Journal of Hospitality Management 31: 675-85. [CrossRef]

Yue, Yang, Zhuang Yan, Anthony G. O. Yeh, Jin-Yun Xie, Cheng-Lin Ma, and Qing-Quan Li. 2016. Measurements of POI-based mixed use and their relationships with neighbourhood vibrancy. International Journal of Geographical Information Science 31: 658-75. [CrossRef]

Žuromskaite, Brigita, and Rafał Nagaj. 2018. Cultural Tourism Facilities in the Context of the Increased Risk of Terrorism: Young Tourists from Lithuania and Security Measures. Turyzm 28: 85-91. [CrossRef]

(C) 2020 by the authors. Licensee MDPI, Basel, Switzerland. This article is an open access article distributed under the terms and conditions of the Creative Commons Attribution (CC BY) license (http://creativecommons.org/licenses/by/4.0/). 